\title{
Estetik Değer Oluşturmada Masalların Rolü: Türk Masalları Örneği*
}

\section{Role of Tales in Creating Aesthetic Values: Turkish Tales Example}

\author{
DOI $=\underline{10.17556 / j \text { jef.92998 }}$
}

\section{Ali Fuat ARICI**}

\section{Özet}

Bireylerin yaşamlarını mutlu ve huzurlu geçirmelerinde onların çocukluklarında bu güzellikleri görme ve yaşamalarının etkili olduğu görülmüştür. Aynı zamanda bu dönemde dinlenen ve okunan materyallerin de hayatta kalıcı izler bıraktığı ve bireyin geleceğini şekillendirmede önemli roller üstlendiği bilinmektedir. Geçmişten bugüne insanların eğlenmesini ve eğitilmesini sağlamanın yanı sıra estetik duygularının gelişmesine de katkı yapan masalların günümüz çocuklarına da önemli katkılar sağlayacağı düşünülmektedir. Sahip olduğu dil ve anlatım özellikleriyle masalların başta bireylerin iyi birer dinleyici olup güzel konuşmaları, topluma yararlı insan olmaları, yaşamı ve çevreyi güzelleştirmeleri, planlı ve düzenli yaşam sürmeleri, edebi zevk kazanmaları, duygu, düşünce ve kavram dünyalarını geliştirmelerine katkı yapacağı kestirilebilir. Araştırmada nitel araştırma tekniklerinden doküman incelemesi tekniği kullanılmıştır. Çalışma grubunun tespitinde amaçlı örnekleme tekniklerinden ölçüt örnekleme kullanılmıştır. Araştırmada, yerli literatürde yer alan eserler ile bazı önemli masal türündeki eserler incelenmiştir. Eserlerin estetik eğitimle ilişkili olup olmadığına bakılmış, estetik eğitime işaret eden cümle veya paragraflar seçildikten sonra kendi aralarında sınıflandırılmıştır. Daha sonra da masallarla estetik eğitiminin nasıl yapılabileceği sorusuna cevap aranmıştır.

Anahtar Sözcükler: Estetik eğitimi, estetik, masal, estetik ve masallar, çocuk edebiyatı

\section{Abstract}

Underlying reason of individuals' spending their lives peacefully and happily is their having seen and lived these kinds of beauties in their childhoods. At the same time, materials read and listened in this period of life leave permanent marks in life and play an important role in shaping the individual's future. From past to present, tales which provide people to be educated and have fun as well as

\footnotetext{
* Bu makale 21-22 Ekim 2016 tarihlerinde İstanbul'da yapılan III. Uluslararası Çocuk ve Gençlik Edebiyatı Sempozyumu'nda sunulan bildirinin genişletilmiş halidir.

** Doç. Dr., Yıldız Teknik Üniversitesi, Eğitim Fakültesi, aricialifuat@gmail.com
} 
contribute to the development of aesthetic senses are also expected to provide important contributions for today's children. With their language and expression features, tales can be estimated to contribute individuals' being good listeners, eloquent speakers, and beneficial to society, beautfying their lives and environment, leading a planned and organized life, gaining literary taste, and enhancing their feelings, ideas and concepts. In the research, one of qualitative research techniques, document analysis was used. The criterion sampling which is one of the purposive sampling techniques was used for determining the extent of the study group. In the study, some works of local literature and some important works of the tale genre were analyzed. Whether the works were associated with aesthetic education was searched and then sentence and paragraphs pointing to the aesthetic education were selected, next, they were classified among themselves. Later on, the answer of the question of "how aesthetic education can be made by the tales" has been sought. literature

Key words: Aesthetic education, aesthetic, tales, aesthetic and tales, children

\section{Giriş}

Günümüzde estetik haz ve anlayış problemi bireysel olmaktan çıkmış küreselleşmeyle beraber tüm dünyayı etkileyen toplumsal bir problem haline gelmiştir. Günlük yaşantımızı oluşturan toplumsal ilişkilerde kullandığımız kelimeler, kulağa hoş gelmeyen cümleler, kıyafetlerimizdeki, evlerimizdeki, eşyalarımızdaki şekilsizlik estetik beğeni fakirliğimizin bir tezahürüdür. Bu olumsuzlukların giderilmesi ise ancak estetik kaygı ve beğeninin zihinlere yerleştirilmesi ve geliştirilmesiyle mümkün gözükmektedir. Bunları kazanacak olan birey de doğal olarak çevresindeki düzensizlik ve çirkinliklerden rahatsızlık duyup bunları değiştirme gayreti içine girecektir.

Bireye estetik duyarlılık kazandırmada en önemli zaman dilimi çocukluk dönemidir. $\mathrm{Bu}$ dönemde kazanılan yaşantılar, okunan kitaplar hayatta kalıcı izler oluşturmakta ve çocuğun geleceğini düşünsel olarak belirlemesinde oldukça etkili olmaktadır. Bu yüzden çocuklara hitap eden edebi eserlerin estetik değerlerinin hayati bir değere sahip olduğu görülmektedir.

Çocuklar okumaya başladıktan ve bu konuda ilerlemeler gösterdikten sonra sürekli olarak edebiyat eserlerinden yararlanmak ihtiyacını duyarlar. $\mathrm{Bu}$ ihtiyacını giderebilmek için sürekli arayış halinde olan çocuk, edebiyat aracılığıyla estetik yönden bakış açısını geliştirebilir ve beğeni seviyesini yükseltebilir (Dedeoğlu Orhun, 2014, s. 602). Jacop (Oğuzkan, 2001) bu ihtiyacın nedenlerini; edebiyatın hoş vakit geçirici, eğlendirici olması, ruha canlılık vermesi ve yaşama gücünü arttırması, hayatı keşfe yardım etmesi, rehberlik 
kaynağı olması, yaratıcı etkinlikleri teşvik etmesi ve güzel bir dil oluşturması olarak sıralamıştır. Felski (2010, s. 82) edebi eserin estetik yönünün bireyi büyülediğini belirterek bunun da edebiyatın dört önemli işlevinden biri olduğunu ifade etmektedir.

Okul öncesi dönemde henüz okuma becerisi edinmemiş çocuklar için kitap bol resim demektir. Bu yönüyle çocuk okuma işlemini resim yorumlayarak ve resmi anlamlandirarak gerçekleştirmektedir. Küçükken edinilen beğeni oluşumu çocuğun ileriki hayatı için önemli bir başlangıçtır. Çocuk bu yönüyle kazandığı estetik duyguyla bir yöntem ve bakış açısı da kazanmış olacaktır.

"Çocuk kitabı her şeyden önce bir sanat eseridir." yargısı, çocuk kitabı yazar ve çizerlerinin uymak zorunda oldukları temel ilke olmalıdır. Bu nedenle, çocuk kitabı yazar ve çizerlerinin çocuğun dünyasını iyi tanıyan, onun ilgi ve gereksinimlerini iyi bilen usta sanatçılar olması gerekir. Çünkü çocukta resim yapma, resim diliyle iletişim kurma isteğinin uyanması ve kitapla çocuk arasında sevgi bağ oluşması için sanatçı duyarlığı ile yapılmış resimlere gereksinim vardır. $\mathrm{Bu}$ duyarlık ile yapılmış resimler, sözcüklerle anlatılanı sanatçının görsel yorumuyla bütünler, metinde anlatılanlara görsel bir renk katar. Resimler yazarın sözel olarak aktaramadığı duygu ve düşüncelerin dışavurumu için öncülük görevi üstlenir. Metnin kurgu özelliğine uygun olarak çocuğu bazen eğlendirir, bazen heyecanlandırır, bazen de düşündürür. Çocuğun görme, duyma, duyumsama, düş kurma, düşünme ve sezme yetilerini harekete geçirir. Çocuklar bu nitelikli resimlere zevkle bakarak kendilerince yeni öyküler oluşturabilir. Böylece, çocuğun renkli ve hareketli dünyasına resmin anlatım diliyle girmeyi başarabilen bir çizer, onların yaratıcılıklarını ortaya çıkararak dil gelişimlerine de katkı sağlamış olur.

Çocuk edebiyatı yayınlarında estetik kaygı sadece resim, çizgi, renk ögeleriyle sınırlı değildir. Kitabın dilindeki estetik de oldukça önemlidir. Duygu ve düşünceleri, olayları ifade ederken şiirsel bir anlatıma sahip olmak, betimlemeleri canlı bir ifadeyle sunabilmek, anlatımda duyulara etkili bir biçimde seslenebilmek bir anlamda çocukta hayal gücü, ifade zenginliği, hoşnut olma ve beğeni kavramlarını geliştirecek bütün bu unsurlar bir araya gelerek estetik bir beğeni ve tavır oluşturacaktır. 
Çocuk edebiyatının en başta gelen kaynaklarından olan masalların dil ve söyleniş biçimi olarak açık, akıcı, kulağa hoş gelen, müzikaliteye sahip olmaları, türün estetik yönünü ortaya çıkarmaktadır. Türün bu özelliği diğer anonim türlerde olduğu gibi halkın dilinde yıllarca gezinip işlenmesinden gelmektedir. Masallar üsluplarının sağlam ve etkililiği sayesinde hem çocuklar hem de büyükler için çok yönlü bir eğitim aracı durumundadır.

Günümüzde değerler eğitimine verilen önem artınca içinde pek çok değer barındıran masallar da yeniden gündeme gelmeye başlamıştır. Örneğin Kantarcıoğlu (1991) araştırmasında masalların eğitimdeki yerini irdelemiş, Helimoğlu Yavuz (1999) masalları eğitimsel iletileri bakımından incelemiştir. Bilkan (2001) büyük ölçüde türün edebi değerini ortaya koyarken Sezer (2010) masalları toplumsal cinsiyet bakımından incelemiştir. Arıcı (2012) ise türün dil ve eğitimdeki kullanımına yer vermiştir. Ancak görüldüğü gibi masalların estetik değerleriyle ilgili henüz bir araştırmaya rastlanmamıştır. Bu araştırma içinde pek çok estetik unsur barındırdığı düşünülen masalları bu yönüyle irdelemeyi ve bunların eğitimdeki yerlerine odaklanmayı amaçlamaktadır.

\section{Bir Dĕger Olarak Estetik ve Ĕ̈itimdeki Yeri}

Güngör (2010) değeri, "bir şeyin arzu edilebilir veya edilemez olduğu hakkındaki inanç" şeklinde açıklarken Tepe (2002) "herhangi bir nedenle iyi olduğu düşünülen, yani kendisine ilişkin pozitif bir değer yargısı bulunan her şey" olarak tanımlamıştır. Yine PrinceGibson ve Schwartz (1998) değerleri "durumlar arası amaçlar ve önemde çeşitlenen bir kişi veya grubun yaşamında rehberlik eden ilkeler" olarak tarif ederken Grünberg (2000) "insan olarak tecrübe edilenin pratik olarak yeniden ortaya konması" şeklinde ifade etmiştir. Değerlerin sınıflandırması ile ilgili olarak Spranger, değerleri altı temel grupta (estetik, kuramsal, ekonomik, siyasi, sosyal ve dini değerler) toplamıştır (Akbaş, 2004). Kirschenbaum (1995) ise değer eğitimi akımlarını karakter eğitimi, vatandaşlık eğitimi ve ahlak eğitimi şeklinde üç ana grupta toplayıp değerlendirmiştir. Güngör (2010) ise sosyal, siyasi, ahlaki, iktisadi, estetik, ilmi ve dini değerler olarak yedi grupta toplamıştır. Görüldüğü gibi çoğu sınıflandırmada "estetik" bir değer olarak yer almaktadır. 
Estetik sözlükte (TDK, 1998: 732) "sanatsal yaratının genel yasalarıyla sanatta ve hayatta güzelliğin kuramsal bilimi, güzel duygu; güzellik duygusu ile ilgili olan veya güzellik duygusuna uygun olan, estetik duygu ve güzelliği ve güzelliğin insan belleğindeki ve duygularındaki etkilerini konu olarak ele alan felsefe kolu" şeklinde tanımlanmaktadir.

Estetik, sanat felsefesinin bir alanıdır. Sanatsal beğeni ve ölçütler estetiksel ölçütlere göre belirlenir. Güzeli güzel yapan ölçütler, değerler bazı yargılarla netlik kazanır. İnsanlarda hoş duygular ve heyecan oluşturan şeylerin inceleme ve değerlendirilmesi estetik ile ilgilidir. Estetik bir anlamda güzel olanın araştırılmasıdır. Güzellik değerinin taşıyıcısı olan şeyler estetik nesne olarak ifade edilir. Sanatı sanat yapan ölçütler estetik biçimlenmeler sanat ürününün ön koşuludur. Bu ölçütler olmadığı, uygun bulunmadığ1 takdirde o sanat ürünü amacına ulaşamaz.

Güzeli sorgulayan bir bilim olan estetik, bir şeyin niçin güzel olduğunu, güzelin ve güzelliğin unsurlarını, iç ve dış kurallarını irdeleyip ortaya koymaya çalışır. Estetik değer damgasını taşıyabilen her şey -güzel ya da çirkin, özgün ya da sıradan, yüksek ya da aşağı, zevkli ya da zevksiz, zengin ya da yoksul olarak değerlendirilebilecek olan her şey şiir ve müzik parçaları, resim ve süsleme, portreler ve manzaralar, yapılar, parklar, danslar-bütün bunlar, ayrı bir bilim olan estetiğin alanına girerler (Geiger, 1993: 128-129).

Psikolojik estetikçiler, sanatın zevk ve tat vermesini, onun en soylu görevi olarak göstermektedir. Kuşkusuz, sanatın sadece yüzeysel etkisinde değil, derin etkisinde de, tam anlamıyla bir zevk etkisi vardır ve bu yadsınmamalıdır (Geiger, 1993: 59). Aslında güzel bir davranış, güzel bir çalışma, güzel bir iş, güzel bir söz, güzel bir yol vb. iyi, yararlı, doğru ve başarılı gibi "değer" kavramıyla eş anlamlı kullanılan "güzel" kelimesi, aslında özel bir değeri, estetik değeri gösterir. Bu özel ve dar anlamında güzel, estetikçe değerli olan şeyle aynı anlamdadır.

Günümüz estetiği, genelde estetik olanı, çağdaş insanın yaşam bütünlüğü içinde temellendirmeyi düşünmektedir. $\mathrm{Bu}$ yaşam bütünlüğü bir yandan değerler sistemi içinde güzel, iyi, doğru, yararlı değerler arasındaki bir senteze ulaşmak isterken, öte yandan da sanat yapıtıyla teknik ürün arasında klasik dönemin taşıdığı engelleri aşarak estetik olanı, insanın kullandığı günlük araç gereçlerde, insanın 
yaşadığı çevre ve kentin biçimlenmesinde bulmak ister. Böyle bir açı altında estetik insanın ortaya koyduğu ve içinde yaşadığ 1 biçim dünyasını araştıran tümel bir bilim olur (Tunalı, 1997: 560).

Edebî metin, okuyucuda bir izlenim bırakmak, bir anlayış, bir duyuş uyandırmak kısacası onda estetik yaşantı adı verilen bir hâlin ortaya çıkmasını sağlamak amacıyla düzenlenir. Ancak edebi eserin tek işlevi bu değildir. $\mathrm{Bu}$, sanat eserini, edebî metni bir işlevle sinırlamak olur. Bu sinırlama gayreti, sanat eserinin varlık sebebine ters düşer ve çok yönlü değer dünyasıyla uyuşmaz. Ancak edebî metnin estetik yaşantı uyandırması önde gelen özelliklerinden biri olarak değerlendirilebilir.

Bireyin eğitimi ileri yaşlarda estetik beğeni ve estetik algılamayı da belirleyecek etkendir. Sanat eğitimi özellikle Batı'da, son derece önemsenmekte ve günümüzde okul öncesi programlarında da yer almaktadır. Bireyin sanat ve estetik eğitiminin, okul öncesi programlara girecek kadar önemli olmasının nedenleri şöyle siralanmaktadır:

Estetik ve sanat, çocuğun gelişiminde yer alan ve var olması gereken kavramlardandır. Estetik eğitimi ile estetik alg1 ve beğenisi gelişecek olan çocuk, çevresindeki güzelliklerin farkına varır harflerin, kelimelerin, sembollerin, şiirlerin, hikâyelerin ve diğer kültürlere sahip insanların değerlerini daha iyi kavrar. Ayrıca estetik deneyimler, çocuğun kavram gelişimini de arttırır (Schirrmacher, 1988).

Estetik duyuları gelişen birey, iyi bir tasarımı değerlendirebilecek duruma gelir. Bunun sonucunda ise araç, giysi, mobilya seçiminden şehirlerin planlanmasına, çevre kirliliği problemlerine kadar pek çok alanda duyarlılığı artar. Estetik bakımdan gelişmiş çocuğun sanata verdiği önem artar ve bu yolla doğrudan çeşitli sanatsal aktivitelere katılımı sağlanabilir.

Öğrencilerin bir sanat eseri karşısında duyarlı tepkiler vermesi amaçlanır ve sanat eleştirisi öğretimi, bu bağlamda öğrencileri estetik alg1 ve estetik beğeni gelişimi açısından her yönüyle doyuracak bir yöntem olarak kabul edilebilir. Öğrencilerin, birbirlerinden farklı sanat yapıtları ile karşılaştırılması, yapıtların görünen olup bittiğinin araştırılması, yapıtın ne anlatmak istediğinin düşünülüp tartışılması gibi çalışmalar, en başta çocuğun görsel olarak algılama becerilerini, 
dikkatini, yorum ve yargıda bulunabilme kabiliyetini daha üst bir seviyeye çekecektir (Özsoy, 2003).

Bahsedilen bu hususların dışında önemli olan nokta çocuk eğitiminde estetik sorunudur. Bunun için çocuklara sunulacak edebi eserlerdeki estetik değerin ihmal edilmemesi gerçeği ortaya çıkmaktadır. Bu yönüyle araştırmanın konusu olan "masalların estetik değer oluşturmadaki rolü" meselesi önemli bir hale gelmektedir.

\section{Yöntem}

Araştırmada nitel araştırma tekniklerinden doküman incelemesi tekniği kullanılmıştır. Çalışma grubunun tespitinde amaçlı örnekleme tekniklerinden ölçüt örnekleme kullanılmıştır. Araştırmada, yerli literatürde yer alan eserler ile bazı önemli masal türündeki eserler (Tezel, 2008; Boratav, 2006; Güney, 1997; Binyazar 2003) incelenmiştir. $\mathrm{Bu}$ eserlerin seçilmesinin sebebi Türkiye'de masal derlemesi konusunda ilk akla gelen ve Türk masallarının niteliğini gösterebilecek eserler olmasıdır.

Çalışmada öncelikle masal konusundaki literatür taraması yapılmış ve estetik ile masalların ilişkisi tespit edilmeye çalışılmıştır. Daha sonra hangi masal metinlerinin analiz edileceğine karar verilmiştir. Seçilen eserlerin analizi alan eğitimi alanında doktorasını tamamlamış üç uzman tarafından gerçekleştirilmiştir. Dokümanın analizinin bu uzmanlar tarafindan yapılmasinın sebebi, bu araştırmacıların hem metin düzeyinde hem edebiyat konusunda hem de pedagoji alanında uzman olmalarıdır. Uzmanlar eserleri "estetik niteliği olması" özelliğine dikkat ederek okumuşlardır. Diğer bir deyişle okunan her cümle veya paragrafın estetik eğitimiyle ilişkin olup olmadığına bakılmıştır. Estetiğe işaret eden cümle veya paragraflar seçildikten sonra kendi aralarında sınıflandırılmıştır. $\mathrm{Bu}$ cümle veya paragrafların yazının konseptine uygun olmasına da ayrıca dikkat edilmiştir. Seçilen bu cümle veya paragraflardan hareketle araştırmada elde edilen bulgulara ulaşılmıştır. $\mathrm{Bu}$ bulgular da benzerliklerine göre sınıflandırılarak sunulmaya çalışılmıştır. Doküman analizinin her aşamasında uzmanlar kendi aralarında tartışmış ve araştırmada üç uzmanın ortak kararları yansıtılmıştır. 


\section{Masalların Estetik Unsurları}

Masalların dil ve söyleniş biçimi olarak açık, akıcı, kulağa hoş gelen, müzikaliteye sahip oldukları görülmektedir. Kısaca masallar oldukça veciz yani etkili ve güzeldir. Masalların bu özelliği diğer anonim türlerde olduğu gibi halkın dilinde yıllarca gezinip işlenmesinden gelmektedir. Masallar üsluplarının sağlam ve etkililiği sayesinde hem çocuklar hem de büyükler için önemli bir güdülenme, hayal kurma ve bilgi sunma aracı durumundadır.

Bir ulusun dil estetiğini, en güzel deyimlerini, en güzel sözcüklerini, ilginç ve dikkat çekici söz kuruluşlarını halk masallarının koynunda buluruz (Demiray, 1986, s. 13). Masallarda yer alan deyim, atasözü, özlü söz, ikilemeler, taklitler benzetmeler, dua ve beddualar başlı başına birer üslup unsurlarıdır. Masallar anlatıldıkları dilin en doğal şekline bürünmüşlerdir. Masaldaki çeşitli dil unsurları (devrik cümleler, benzetmeler, deyim ve atasözleri) konuşma dilinin samimiliği içerisinde ortaya konmakta bu da türün doğallığına katk1 yapmaktadır.

Masallar çoğunlukla halk içinden çıkıp yine halk için anlatılan türler olduğu için (gazete gibi) onların dillerinin yalın bir şekilde olması doğaldır. Bütün dünya masalları gibi Türk masalları da dilsel olarak bu özelliktedir. Anlatımda betimlemeler oldukça az yer alır. Masalın bütününe oldukça hareketli bir dil hâkimdir. Böyle olunca da betimleme değil, eylem ağırlıklıdır. Genellikle sıfatlar az kullanılırken fiiller çok kullanılır. Bu da hareketliliği sağlayan temel ögedir (Helimoğlu Yavuz, 1999, s. 81).

Masalın dinleyen kişilerde uyandırdığı duygular, onların zihninde çeşitli imgeler oluşturur. $\mathrm{Bu}$ imgeler estetik duyguları harekete geçirir. Bilkan (2001, s. 31) bu estetik duyguları büyüye benzetir ve kendisini büyünün etkisine bırakan kişinin duyduğu hazla, masal dinlemeye başlayan kişinin kendisini tümüyle ifadenin sihrine bırakarak duyduğu hazzın aynı haz olduğunu ifade etmektedir. Bilkan ayrıca masal ile hipnoz arasında da benzerlikler olduğunu belirtmekte ve masallarda hâkim olan telkin özelliğinin büyüye zemin hazırladığını düşünmektedir. 


\section{Masalların Estetik Dil Unsurlart}

Masalların dil ve üslup bakımından sahip oldukları estetik özellikleri şöyle sıralayabiliriz:

Masalın ve anlatıcısının üslubu. Masallar, anlatıcının ağız özelliklerine ve masalın anlatıldığı yörenin mahallî niteliklerine göre her anlatılış sırasında değiştirilip yeniden şekillenir. Anlatıcının dil becerisi, birikimi ve kültürü masalın etkisini artırabilir. Masalın gerçek üslubu ancak etkili bir anlatıcıyla kendini gösterir. Jestleri, mimikleri ve beden diliyle birlikte masalın anlatımında kullanılması gereken formellerin yerli yerinde kullanılması, masalın üslubunun hakkıyla ortaya çıkmasını sağlar. İyi bir masalcı da zaten masalın doğasında var olan bu renkli ve etkili üslubu ortaya koyan kişidir.

Etkili başlangıç. Masallar tekerlemelerin şiirsel özelliği ile masala bir taraftan ahenk katarken diğer taraftan merak artırmaktadır. Masalla hiçbir ilgisi olmayan tekerlemenin masal başında söylenmesinin tek amacı, sadece dinleyicinin ilgisini çekmek ve onu masal dünyasına girişe hazırlamaktır. İşte masalcının söz ustalığı da burada başlar. Söylediği tekerlemeyle dinleyenleri neşelendirir. Anlatacağı masala ilgi çeker. Masalının dikkatle ve heyecanla dinlenmesini sağlar. (Tekerleme/ata-sözü/deyim= söz güzelliği)

Konuşma dilinin içtenliği ve rahatllğg. Masallar öncelikle sözlü edebiyatın mahsulleri olarak konuşma dilinin doğallığı içinde gelişmiş bir türdür. Bu özelliği ile akıcı ve rahat anlaşılır bir dile sahip olmuştur.

Nükteli anlatım. Masalda halk söyleyişleriyle dolu, çoğu zaman mizahî bir karakter kazanmış dil kullanılır. Masallardaki gülünç ifadeler, alaycı sözler ve komik durumlar, dinleyicinin dikkatini toplayan ve masal metnini zevkli bir hâle getiren unsurlar olarak önemli bir yere sahiptir.

Ifade zenginliği. Deyim, atasözü, özlü söz, ikileme, taklit, benzetme, dua ve beddualarla zenginleștirilen masallar, dilin inceliklerini temsil eden edebî metinlerdir.

Edebî sanatların kullanımı. Masallarda geçen teşhis, intâk, teşbih, istiâre (özellikle hayvan masallarında) mecaz ve kinâye gibi edebî sanatlar, masalların dil zenginliğine önemli katkı sağlamakta ve masalların gücünü artırmaktadır. Bilkan (2001, s. 71) "Üç Turunçlar" adlı Türk masalında 104 adet deyim, atasözü, özlü söz ve sembolik 
ifade bulunduğunu tespit ederek çocuğun dağarcı̆̆ında yer almayan birçok ifadenin masal içerisinde yer alan konu, cümle yapısı ve yardımcı ögeler vasıtasıyla anlaşılır hâle geldiğini ve dinleyicinin bu tür ifadeleri anlamasının kolaylaştığını ifade etmektedir.

\section{Masalların Estetik Değer Unsurları}

Sezer (2010, s. 125) masallarda en çok işlenen konuların başında "güzellik" geldiğini belirtmektedir. İncelediğimiz Türk masallarında yer alan bazı estetik değerleri şöyle özetleyebiliriz:

"Bir Göze Bir Gül” ve "Altın Bülbül” masallarında (Tezel, 2008) ve "Dev Baba" masalında (Binyazar, 2003) güzellik değeri anlatılmıştır:

“...Bir gün haber almışlar ki, falan memlekette ağladıkça gözlerinden inciler dökülen, güldükçe yanaklarında güller açan güzel bir kız var."

“...Kız gülmüş. Gülünce yanaklarından kırmızı güller açmaz mı? İhtiyar adam, kızın yanaklarında kırmızı gülleri görünce hem şaşırmış hem de sevinmiş."

“...Cami o kadar göz alıcıymış ki, göklere yükselen beyaz minareleri uzak şehirlerden bile görülüyor, altın yaldızlı kubbeleri güneş gibi parıldıyor, yüzlerce penceresindeki renkli camlardan içeriye çeşitli ışıklar sızıyormuş."

"Nasıl da güzelmiş kız; sanki periler arasından çıkıp gelmiş bu dünyaya!"

"Nohut Oğlan" masalında (Binyazar, 2003) mutluluk değerine atıf vardır:

"...Gildır gildır (yuvarlacık) nohudum ana kurban sana, hadi şu ekmeği al da babana götür, oğlunun aş getirdiğini görüp sevinsin baban," demiş."

"Çifte Kanbur" masalında (Tezel, 2008) ise güler yüzlü olmanın değeri anlatılmaktadır.

“...Ş̧eytanlar, oynarlarken, bir köşede büzülerek uyuyakalmış Kambur Ali'yi görmüşler. Yanına koşarak onu uyandırmışlar. Onun güler yüzünden çok hoşlanan şeytanlar, kendisini de aralarına alarak oynatmak istemişler.

Kanbur Ali gülerek: 
Hay, hay, oynayalım, demiş. Hem ben çok güzel oynarım. Ama ah şu sırtımdaki kambur olmasa!.."

"Yeni Gelin ile Yolcu" masalında (Sarıyüce, 1979) anlayışlı olma konusu işlenmiştir.

“... Yolcu da arif bir kişiymiş. Gelinin ne demek istediğini hemen anlamış:

- Kızım demiş, helvaya tuz konmaz, git de helvanı tuzsuz pişir! İnsan dediğin anlayıșlı olmalı, leb demeden leblebiyi anlamalı.

"Gururlu Kız" masalında (Tezel, 2008) alçakgönüllü ve güler yüzlü olmanın değeri anlatılmıştır.

“...Güzel kız, o günden sonra gururu bırakmış. Alçakgönüllü güler yüzlü olmuş. Günün birinde de, zengin bir vezirin yakışıklı oğlu ile evlenmiş, muradına ermiş..."

\section{Masallarla Estetik Değer Eğitimi}

İlköğretim Türkçe Dersi $(6, \quad 7, \quad 8 . \quad$ sinıflar $)$ Öğretim Programında (MEB, 2006) "Okuma Metinlerinde Bulunması Gereken Özellikler” başlığı altında ifade edilen özelliklerden biri çocuklara "estetik değer" kazandırmakla ilgilidir:

"Metinler, öğrencinin kişisel gelişimine katkıda bulunacak ve onlara estetik bir duyarlılık kazandıracak nitelikte olmalıdır." Bunun için edebi eserlerde okuyucunun beğenisini geliştirecek bir tutum oluşturmak gerekir. $\mathrm{Bu}$ ancak belirlenen ölçütlere göre yazılan eserlerle karşılaşmakla mümkündür. Kişi estetikle ne kadar erken tanışırsa sanat ve dolayısıyla edebiyatın içinde o kadar yol almış olacaktır. Bunun için çocuk kitaplarının oluşumunda biçimsel ve içeriksel yapı birlikte değerlendirilmeli; içeriksel yapı çocuğun düşünce ve hayal dünyasına uygun olmakla birlikte, bunu tamamlayan bir unsur olan biçimsel görünüş, kitap resimlerinin seçimine estetik değer açısından dikkatle eğilinmeli ve sanatın kişide zevk oluşturma, kişiye haz verme düşüncesiyle yapılması için hedefler belirlenmelidir.

Masallar, içerdiği pek çok özelliğiyle bireylerin estetik yönden gelişmesine katkı yapacak niteliktedir. İnsanlığın var olduğu ilk çağlardan beri toplumun içinde gezinen bu hayalî tür, her neslin içinden geçen, farklı güzellikleri toplayıp bugüne kadar getiren bir ırmağa ya da halkın dilinden, kültüründen topladığı güzelliklerle yuvarlana yuvarlana büyüyen ve bunu daha ilerilere taşıyan bir 
kartopuna benzetilebilir. Masallar da âdeta bu iki doğa olayı gibi, her geçtiği çağın bin bir türlü özelliğini alarak yeni bir çağa doğru yol almış, sonunda da eriyerek verimli ovalar oluşturmuş ve yetişen yeni nesillere geçmişin birikimini sunmuştur.

Masallar anlatıldıkları dilin en doğal şekline bürünmüşlerdir. Masaldaki çeşitli dil unsurları (devrik cümleler, benzetmeler, deyim ve atasözleri) konuşma dilinin samimiliği içerisinde ortaya konmakta bu da türün doğallığına katkı yapmaktadır (Arıcı, 2012). Masalların sahip olduğu bu estetik dil ve değer unsurları onları okuyan, dinleyen ve anlatanların da çeşitli yönlerden bunları kazandıkları düşünülebilir. Şimdi bunları açıklayalım:

Güzel konuşma. Masallar için anlatıcı ve onun özellikleri çok önemlidir. Anlatıcı bilgili, birikimli, hoşsohbet ve hepsinden öte iyi bir hatipse, masal da bu paralelde etkili bir masal olur. Çünkü masallar şiir gibi her zaman aynı şekilde kalan, değişmeyen bir tür değil; aynı temanın farklı kelimelerle anlatıldığ 1 "esnek" bir türdür. Usta masal söyleyiciler onları her anlatışlarında biraz değiştirmişlerdir. Konusu aynı olan bir masalın yüzlerce değişik söyleyişi bulunabilir. Halis bir söz sanatı olan masal kâğıda geçerken birçok özelliğini kaybeder. Çünkü masalda konu değil masalcının anlatışı önemlidir (Güleç, 2002, s. 79). İyi bir masalcı her şeyden evvel kendisini karşısındakine kabul ettirmek zorundadır. Anlatışındaki açıklık ve devamlılık masalcıyı bize sevdirir. Devamlı olarak masal anlatan bir kişinin bu hususları taşıyacağı tabiidir. Masalın kalıplaşmış bir yapısı yoktur. Her anlatıcı aynı hadiseyi değişik kelimelerle anlatabilir. Masal anlatıcılarının sahip olması gereken özelliklere bakıldığı zaman bunların iyi bir hatipte de bulunması gereken özellikler olduğu görülmektedir. Bütün bunlardan anlaşılmaktadır ki iyi bir masal anlatıcısı, aynı zamanda iyi bir hatiptir. Masal dinleyicileri de bir taraftan masal âleminde yol alırken diğer taraftan güzel konuşmayı öğrenmekte ve konuşmaları estetik bir hale bürünmektedir.

Güzel ve yararlı bir kişilik oluşturma. Türk halk edebiyatı ürünlerinin -özellikle anonim olanlarının- en temel özelliklerinden biri kahraman tipleridir. Oğuz Kağan ve Manas Destanları ile Köroğlu ve Dede Korkut gibi eserlerdeki kahramanların büyük ölçüde geleneksel bir yol izleyerek "haktan, mazlumdan yana" tavır koymuş oldukları ve bunun mücadelesini verdikleri görülmektedir (Kaplan, 2005). Doğrudan, haklıdan, iyiden ve güzelden yana bir eğitimin birçok 
masalda çimlendiğini hep biliriz. Bu bakımdan çocuğun gelişimine en etkili katkıyı masallar sağlar (Demiray, 1986, s. 13). Türk masallarını da bu çerçevede değerlendirebiliriz. Pek çok masalda görüldüğü gibi kahramanlar, kötülerle ve kötülüklerle mücadele etmekte; iyilik ve güzellik için mücadele vermektedirler. $\mathrm{Bu}$ da dinleyenlerin hem iç dünyalarının (ahlaki yönlerinin) hem de hal ve davranışlarının güzelleşmesine katkı sağlamaktadır.

Yaşamı güzel kılma. Tarihin her döneminde insanoğlu, bașına gelen sıkıntılı durumlardan kurtulabilmenin çarelerini aramıştır. Geçmişin yönetici merkezli problem çözme geleneğine mensup masal çağının insanı da sıkıntılı ve kederli anlarında kendini masal kahramanlarında avutmuş ve onlar gibi bir gün kendinin de istediği şeylerin gerçekleşeceği ümidiyle yaşamıştır. Masalların hayali olay ve kahramanları vasıtasıyla kendine ayna tutmuştur. Özlemlerini ve umutlarını bu sembolik figürlerle dile getirerek kendi iç dünyasını dışa vurabilmiş yani rahatlayabilmiştir. Bu sayede insanlar bir nevi iç huzura kavuşmuşlardır. Bu yönüyle masalların insanlar için bir nevi "terapi” vazifesi gördüğü düşünülebilir. Türk masalları dinden gelen tevekkül duygusunu güçlendirerek insanların kadere boyun eğmesini kuvvetlendirmiş ve dolayısıyla olumsuz durumlar karşısında sabır telkin etmiştir. Bu durum insanların yaşamını güzel ve mutlu kılmıştır. İyiliklerin ve güzelliklerin ödüllendirilmesi. Masalların sonunda genelde iyiler kazanmakta, güzellikler ödüllendirilmektedir. Masalların sonunda iyilik ve güzelliklerin, sağduyulu kişilerin kazanması dinleyenlere psikolojik bir rahatlama imkânı sağlarken kötülerin, yalancıların, hırsızların, haksız kişilerin cezalandırılması, gerçek hayattaki uygulamalar karşısında bunalan ve ümitsizliğe düşen insanları yeniden hayata bağlamaktadır. Böylece masallar çocukların ruh dünyalarında daima iyinin, doğrunun ve güzelin galip geldiğini işaret ederek bu hasletlerin yerleşmesini sağlamaktadır (Bilkan, 2001, s. 35). Yani masallarla bibliyoterapi (kitaplarla terapi) yapilarak (Yeşilyaprak, 2008, s. 20-22) insanların estetik yönden gelişmelerine de katk1 sağlanabilir. Nitekim Charrier ve Ozouf (Kantarcıŏglu, 1991; s. 34) da masalların çocuklara okunup okutulmasıyla bir taraftan onların belleklerinin gelişmesi kolaylaşıp kompozisyon için hazırlık yapılırken diğer taraftan çocukların edebî zevki geliştirilip kötü telaffuzlarının düzeltilmesi sağlanmış olduğunu belirtmektedir. 
Edebi zevk kazanma. Kişilerin dil ve edebiyat zevklerinin oluşması ve gelişmesine masalların önemli katkısının olduğuna şüphe yoktur. Mesela şair ve yazar Ahmet Hamdi Tanpınar (2000) çocukluğunda iyi bir eğitim alamamasına rağmen edebiyata meyilli olmasını çocukken okuyup dinlediği "Binbir Gece Masalları"na bağlamaktadır. Yine aynı şekilde Kırgız Yazar Cengiz Aytmatov'da edebiyata merakını ninesinden dinlediği masallara borçlu olduğunu söyler (Kolcu, 2002). Masal dinleyicisi, sürekli karșısında iyi konuşan birisini gördüğü için bundan etkilenmemesi beklenemez. Okunan dinlenen masallar üzerine yukarıda belirtilen çeşitli çalışmaların sözlü ve yazılı olarak yaptırılması her iki becerinin gelişmesini sağlayabilir. Dinlediği masalları başkasına anlatan çocuk, her masalda sade ve rahatça anlaşılır bir dili kullanarak kazanmış olacaktır (Gürel, Temizyürek ve Şahbaz, 2007, s. 54)

Sözü etkili kılma. Masal tekerlemelerinin masallardaki kullanım amaçları dikkat çekmeye yöneliktir. Aslında masalla hiçbir ilgisi olmayan tekerlemelerin masallarda yer almasının amacı dinleyicinin ilgisini çekmek ve onu masal dünyasına girişe hazırlamak içindir. Masalcı söylediği tekerlemeyle dinleyenleri neşelendirir. Anlatacağı masala ilgi çeker. Masalının dikkatle ve heyecanla dinlenmesini sağlar. Bu bağlamda tek başına bir masal bile başlı başına bir ders olarak da düşünülebilir. Öyle ki tekerlemeyle yani çekilen dikkatle başlanan masal, çeşitli olaylarla gelişmekte ve değerlendirme yani verilen, çıkarılan dersle bitmektedir. Bu noktadan hareketle çok masal dinleyen ve anlatanların etkili ve güzel söz söyledikleri hatta sözün ustası haline geldikleri söylenebilir.

Plan ve düzeni öğrenme: Tahkiyeye dayalı her tür gibi masallar da belli bir düzene sahiptir. İlginç ve ilgi çekici bir tekerleme ile başlayan masallar, kahramanların tanıtımıyla devam etmekte (serim) çeşitli olaylarla gelişmekte (düğüm) ve dilek, temenni veya duayla sonuçlanmaktadır (çözüm). Masal bölümleri, diğer türlere göre daha belirgindir. Bu düzen ve plan sayesinde öğrencilerin "estetik" algılarına katkı sağlanabilir.

Düşünce ve kavram dünyasını geliştirme: Masallar kelime çeşitleri ve ifade kalıpları (deyim, atasözü, özlü söz, ikilemeler, taklitler benzetmeler, dua ve beddualar gibi) açısından oldukça zengindir. Bireylerin bunları okuması, dinlemesi ve anlatması (sözlü ve yazılı) zamanla bunları edinmesiyle sonuçlanacaktır. Sözlü-yazılı 
anlatımın ve dolayısıyla düşüncenin gelişmesi için iyi bir kelime hazinesi son derece önemlidir. Bu da onların düşünce dünyalarına çeki düzen verecek ve sorunlarını çözmelerini kolaylaştırıp daha iyi ve güzel bir hayat sürmelerine sebep olabilir.

Ancak bütün masalların bu konuda faydalı ve etkili olacağını düşünmek zordur. Özellikle son dönemde ticari maksatla ortaya konan masalların bu estetik özelliklerden mahrum olduğu bilinmektedir. Bunun için seçilen masal örneklerinin akıcı üslûp ve anlatımı, kısa ve uyaklı cümle yapısı, "güzellik, iyilik, doğruluk" gibi estetik değerleri ele alması vb. özelliklerinden yararlanılarak bir yandan çocuğun hayal gücü, yaratıcı ve eleştirel düşünme becerisi geliştirilebilir. Bu noktada seçilecek masal örneklerinin, tamamen ilgi çekici ve sürükleyici olmasına özen gösterilmelidir. Özellikle öğrencilerin ilgisini, daha çok onların duygularına hitap edebilen, içerisinde kendilerini bulabilecekleri, kahramanların yerine kendilerini koyabilecekleri vb. ilişkiler ağı içerisinde olabilecekleri metinler çekmektedir. Metinler özellikle "iyilik, doğruluk, dostluk, arkadaşlık", gibi estetik ve etik değerleri ele almalıdır. Böylece hem çocuklarda estetik zevk oluşturulacak hem de olumlu kişilik özellikleri kazandırılmış olunacaktır.

\section{Sonuç ve Tartışma}

Bireylerin yaşamlarını mutlu, huzurlu ve güzelliklerle dolu geçirmelerinde onların çocukluklarında bu güzellikleri görme ve yaşamalarının etkili olduğu görülmüştür. Aynı zamanda bu dönemde dinlenen metinlerin ve okunan kitapların da hayatta kalıcı izler bıraktığ1 ve çocuğun geleceğini şekillendirmede önemli roller üstlendiği söylenebilir. $\mathrm{Bu}$ yüzden çocuklara hitap eden edebi eserlerin estetik değerlerinin hayati bir değere sahip olduğu görülmektedir.

Sözlü gelenek içerisinde yıllarca halkın dilinde gezinerek bugünkü hâle gelen masalların dilden dile kulaktan kulağa aktarılması onların açık, akıcı, kulağa hoş gelen, müzikaliteye sahip olmalarını sağlamıştır. Masallar üsluplarının sağlam ve etkililiği sayesinde büyük beğeni toplamış ve insanların güzellik duygularına hizmet etmiştir. Masallardaki bu estetik değerlerin günümüz çocuklarına da önemli katkılar sağlayacağı düşünülmektedir. $\mathrm{Bu}$ kadim türün özellikle 
bireylerin iyi bir dinleyici olmalarında, güzel konuşmayı görme ve ögrenmelerinde, topluma faydalı bir insan olmalarında, kendi yaşamlarını ve çevresini güzelleştirmede, iyilik ve güzelliklerin ödüllendirilmesinde, edebi zevk kazanma ve bunu devam ettirmede, planlı ve düzenli yaşam sürmede ve kavram ve düşünce dünyasını geliştirmede katkı sağlayacağı varsayılabilir.

Masalların estetik değer oluşturmada kullanılabilmesi için öncelikle bu yönü güçlü olan masalların derlenip toplanarak bunların basım ve yayımının sağlanması gerekmektedir. Daha sonra da özellikle anne karnından başlayarak nitelikli masal metinlerinin önce bebeklerle daha sonra da çocuklarla buluşturulması gerekmektedir. Ayrıca bunların çizgi filmlerle çocuklara ulaştırılması sağlanabilir. Yine estetik değere sahip yeni masalların yazılması sağlanabilir. Son olarak ders ve okul ortamında yapılacak çeşitli etkinliklerle (resim, drama, tiyatro, pantomim vd.) çocukların estetik yönden gelişmelerine yardımcı olunabilir.

Son olarak edebiyat, malzemesi dil olan bir sanattır. Bu sanatın ürünleri olan edebî eserler edebî tür denilen yapılar içerisinde dilin daha özel kullanılmasıyla vücut bulurlar. Edebî eserler güzelin dil aracılığıyla oluşturulan görünümleridir. Bunun için estetik değer kazandırmada edebiyattan ve dolayısıyla masallardan yararlanılabilir.

\section{Kaynaklar}

Akbaş, O. (2004). Türk milli eğitim sisteminin duyuşsal amaçlarının ilköğretim ikinci kademedeki gerçekleşme derecesinin değerlendirilmesi. Yayımlanmamış doktora tezi. Ankara: Gazi Üniversitesi Eğitim Bilimleri Enstitüsü.

Arıcı, A. F. (2012). Masalın sesi, Ankara: Pegem Akademi Yayınları.

Bilkan, A. F. (2001). Masal estetiği, İstanbul: Timaş Yayınları.

Binyazar, A. (2003). 15 Türk msalaı. İstanbul: Can Yayınevi.

Boratav, P. N. (2006). Az gittik uz gittik. İstanbul: İmge Yayınevi.

Dedeoğlu Orhun, B. (2014). Estetik kavramı çerçevesinde çocuk edebiyatı, Türk Dili, 756: 602-607.

Demiray, M. G. (1986). Halk masalları üzerine görüş ve düşünceler, Türk Folkloru, 86: $10-13$.

Dilmaç, B. (2002). Insanca dĕ̌erler ĕgitimi, Ankara: Nobel Yayınları.

Felski, R. (2010). Edebiyat ne işe yarar? İstanbul: Metis Yayıncılık. 
Geiger, M. (1985) Estetik anlaylş, İstanbul: Remzi Kitabevi.

Güleç, H. (2002). Türk halk edebiyatı, Konya: Çizgi Kitabevi Yayınları.

Güney, E. C. (1997). Masallar. Ankara: Kültür Bakanlığı Yayınları.

Güngör, E. (2010). Değerler psikolojisi üzerine araştırmalar, İstanbul: Ötüken Neşriyat.

Grünberg, L. (2000). The mystery of values: Studies in axiology, (ed. by C. Grünberg \& L. Grünberg) Amsterdam-Atlanta: Editions Radopi Press.

Gürel, Z., Temizyürek F. ve Şahbaz, N. K. (2007). Çocuk edebiyatı, Ankara: Öncü Kitap.

Helimoğlu Yavuz, M. (1999). Masallar ve eğitimsel işlevleri, Ankara: Ürün Yayınları.

Kantarcıoğlu, S. (1991). Eğitimde masalın yeri, İstanbul: MEB Yayınları.

Kaplan, M. (2005). Türk edebiyatı üzerine araşstrmalar 3 tip tahlilleri, İstanbul: Dergâh Yayınları.

Kolcu, A. İ. (2002). Bozktrdaki bilge Cengiz Aytmatov, Ankara: Akçağ Yayınları.

MEB. (2006). İlköğretim okulu türkçe dersi öğretim programı, Ankara: Eğitimi Araştırma ve Geliştirme Dairesi Başkanlığı Yayınları.

Oğuzkan, F. (2001). Çocuk edebiyatı, Ankara: Anı Yayınc1lık.

Özsoy, V. (2003). Görsel sanatlar eğitimi. Ankara: Gündüz Eğitim Yayıncılık

Prince-Gibson, E. \& Schwartz, S. H. (1998). Value priorities and gender, Social Psychology Quarterly, 61: 49-67.

Sarıyüce, H. L. (1979). Ders veren Türk masalları, Türk Folklor Araştırmaları Dergisi: 18: 8533-8535.

Schirrmacher, R. (1988). Art and creative development for young children. Delmar Publisher Inc. USA.

Sever, S. (2003). Çocuk ve edebiyat, Ankara: Kök Yayıncıllk.

Sezer, M. Ö. (2010). Masallar ve toplumsal cinsiyet, İstanbul: Evrensel Yayınları

Tanpınar, A. H. (2000). Yaşadı̆̆ım gibi, İstanbul: Dergâh Yayınevi.

Tepe, H. (2002). Değerler ve değer bilgisi, bilgi ve değer sempozyumu bildirileri, Ankara: Vadi Yayınları.

Tezel, N. (2008). Türk masalları. İstanbul: Bilge Kültür Sanat Yayınları.

Timuçin, A. (1993). Estetik, İstanbul: İnsancıl Yayınları.

Tunal, İ. (1996). Estetik, İstanbul: Remzi Kitabevi.

Yeşilyaprak, B. (2008). Bibliyoterapi: Okuma ile sağaltım, Çoluk Çocuk Dergisi, 82: $20-22$.

Yıldırım, A. \& Simşek, H. (2006). Sosyal bilimlerde nitel araştırma teknikleri. Ankara: Seçkin Yayınevi. 


\section{Extended Summary}

The concern of aesthetic in the children's literature is not only limited to illustration, shape or color elements. Aesthetic in the language of books is also highly important. Having a poetic expression when expressing the events, thoughts and feelings, being able to present the descriptions with a vivid expression, and being able to appeal to the senses in an effective manner in a narration will develop the concepts of imagination, amplidute, satisfaction and appreciation in children. And all these elements will become integrated and generate an aesthetic appreciation and attitude.

Tale, one of the leading source of children's literature, has a clear, smooth and tuneful musicality as a form of language and pronounciation and these features reveal the aesthetic aspect of the genre. This aspect comes from being in the limelight of public over the years as in the other anonymous genres. Thanks to solidity and effectiveness of its wording style, a tale is a versatile education tool for both children and adults.

Document analysis technique, which is one of the qualitative research techniques, was used in this research. Criteria sampling technique from purposeful sampling techniques was used in determining the study group. In the study, some local literature works and some important works in the tale genre (Tezel, 2008; Boratav, 2006; Güney, 1997; Binyazar 2003) were analyzed. The reason for choosing these works is their coming to mind first about tale collection in Turkey and their being kinds of works which can show the nature of Turkish tales.

In the study, firstly literature review was made and tried to be identified the aesthetics and tale relationship. Later on, which tale texts would be analyzed was decided. Analysis of the selected works were carried out by three specialists who have completed their doctorate degrees in this field. The reason why document analysis was made by these experts is that these researchers are experts in both pedagogy and literature as well as text. The experts have read the works paying attention to their feature of "having aesthetic qualities". In other words, whether each read sentence or paragraph was related to aesthetic education was considered.

After the sentences and paragraphs which pointed to asthetics were selected, they were classified among themselves. It has also been noted if the sentences or paragraphs were suitable with the concept of the text. Starting from these selected sentences or paragraphs, the findings obtained in the study have been reached. These findings have also been classified according to their similarities. At every stage of the document analysis, three specialists discussed with each other and their joint decision was reflected in the study.

In conclusion, literature is an art whose material is language. These literary works which are the products of this art are embodied by using the language more specially among the forms called literary genre. The literary works are the views of beautiful which are created through language. Therefore, literature and tales can be utilized in order to give aesthetic value 
A nation's language aesthetics, most beautiful idioms, most beautiful terms, interesting and noteworthy words or sentences can be found in the bosom of the folk tales (Demiray, 1986, p. 13). Idioms, proverbs, aphorisms, repetitions, imitations, prayers and curses in the tales are the elements of wording each one of all. Tales have been transformed into the most natural form of the language they are told. The various language elements of tales (inversions, metaphors, idioms and proverbs) are revealed in the sincerity of spoken language and this contributes to the naturality of this genre. Since the tales mostly come out from the public and are told for the public again, their language's being simple is natural (like newspapers). Like all the world tales, Turkish tales have the same linguistic features. Descriptions in manner of telling are quite less. A fairly dynamic language dominates over the whole tale. Therefore, actions are predominantly used, instead of descriptions. Usually verbs are preferred to be used more, while adjectives are used less. This is the basic element providing dynamism (Helimoğlu Yavuz, 1999, p. 81).

The emotions aroused in people while listening the tale generate various images in their minds. These images stimulate the aesthetic senses. Bilkan (2001, p. 31) compares these senses of aesthetics with a spell and implies that with the pleasure which the person feels leaving himself to the effect of a spell and the pleasure which the person feels leaving himself to the spell of the expressions of the tale while listening feel the same pleasure. Bilkan also states that there have been similarities between hypnosis and tale and thinks that the feature of predominating inculcation in tales lays the groundwork for the spell.

However, it is difficult to think that all tales would be useful and effective in this regard. Especially recently published tales with commercial purposes is known to be deprived of these aesthetic features. For this reason, by benefiting from the features of selected tale examples, such as; their fluent stylistic and narration, short and rhymed sentence structure, and handling the aesthetic values of "kindness, goodness and righteousness", child's imagination, creative and critical thinking skills can be developed. At this point, selected tale samples should be completely attractive and immersive. In particular, the texts draw students' interests are the ones that will appeal to their emotions, they find themselves in, and they put themselves in the place of tale heroes. Tale texts should handle the aesthetic and ethical values especially the values of "goodness, rightousness, friendship, etc.". Thus, both aesthetic pleasure and positive personality traits will have created on children.

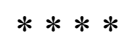

